\title{
Papers
}

\section{Observational study of vaccine efficacy 14 years after trial of hepatitis B vaccination in Gambian children}

\author{
Hilton Whittle, Shabbar Jaffar, Michael Wansbrough, Maimuna Mendy, Uga Dumpis, \\ Andrew Collinson, Andrew Hall
}

\begin{abstract}
Objective To determine the duration of protection from hepatitis B vaccine given in infancy and early childhood.

Design Cross sectional serological study of hepatitis B virus infection in children of various ages 14 years after the start of a trial of vaccination regimens.

Setting Two villages in the Gambia.

Participants Children and adolescents given hepatitis $B$ vaccine in infancy or early childhood: 232 were aged $1-5$ years, 225 aged $5-9$ years, 220 aged $10-14$ years, and 175 aged $15-19$ years.

Main outcome measures Vaccine efficacy against infection and against chronic infection in the different age groups.

Results Vaccine efficacy against chronic carriage of hepatitis B virus was $94 \%$ (95\% confidence interval $89 \%$ to $97 \%$ ), which did not vary significantly between the age groups. Efficacy against infection was $80 \%$ (76\% to $84 \%)$. This was significantly lower in the oldest age group $(65 \%, 56$ to 73$)$. Of the uninfected participants in this age group, $36 \%$ had no detectable hepatitis B virus surface antibody. Time since vaccination and a low peak antibody response were the most powerful risk factors for breakthrough infection ( $\mathrm{P}<0.001$ in each case). Low peak antibody response was also a risk factor for chronic carriage (odds ratio 95, 19 to 466).

Conclusions Children vaccinated in infancy are at increased risk of hepatitis $\mathrm{B}$ virus infection in the late teens. The risk of chronic carriage after sexual exposure needs further assessment to determine if booster vaccines are necessary.
\end{abstract}

\section{Introduction}

Chronic infection with hepatitis B virus is a leading cause of death from cancer in Africa; a quarter of the 60 million carriers die either of primary hepatocellular carcinoma or cirrhosis of the liver. ${ }^{12}$ However, although hepatitis $\mathrm{B}$ vaccination is the simplest and most effective intervention to prevent mortality in adults both globally and in Africa, ${ }^{2}$ only one country in west Africa and two in southern Africa have a continuing vaccination programme.

The Gambian programme was started in 1986 as part of a 40 year trial to test the efficacy of vaccination against hepatitis B in the prevention of hepatocellular carcinoma. ${ }^{3}$ Before this trial epidemiological studies were undertaken in the two villages of Manduar and Keneba, where transmission of hepatitis B virus was found to be largely horizontal, from older to younger children, and rates of infection and chronic carriage, which were high, varied markedly between the villages. ${ }^{45}$ Trials of different routes of administration of vaccine were started in these villages in $1984^{6}$ and vaccination has been continued thereafter. ${ }^{78}$ Nine years later vaccine efficacy against either infection or chronic carriage was 93\%.8 Another long term study from Senegal, which was small due to major losses to follow up, reported efficacies 9 to 12 years after vaccination of $63 \%$ fir infection and $87 \%$ for chronic carriage. ${ }^{9}$

We investigated vaccine efficacy against infection and protection against chronic carriage after 14 years.

\section{Methods}

The demographic and medical background of the villages of Keneba and Manduar, which in 1998 had populations of 1474 and 607 respectively, has been described previously. ${ }^{4}$ Surveys of hepatitis B virus infections in these villages took place in 1973, 1980, ${ }^{4}$ $1984,{ }^{5} 1989,{ }^{7}$ and $1993^{8}$ and from November 1998 to March 1999. At the time of the third survey in November 1984 all children under the age of 5 years who were seronegative for hepatitis B virus infection were vaccinated. These children were assigned randomly to receive plasma derived vaccine against hepatitis $B$ virus (H-B-Vax, Merck Sharpe \& Dohme) according to one of three vaccination regimens: group 1 was given three doses of $2 \mu \mathrm{g}$ intradermally, group 2 received $2 \mu \mathrm{g}$ intradermally followed by two $20 \mu \mathrm{g}$ intramuscular doses, and group 3 received three doses of $20 \mu \mathrm{g}$ intramuscularly. ${ }^{5}$ Subsequent vaccination of newborn infants has continued with four doses of various vaccines given intramuscularly: group 4 received $10 \mu \mathrm{g}$ $\mathrm{H}-\mathrm{B}-\mathrm{Vax}$, group 5 received recombinant vaccines $(5 \mu \mathrm{g}$ Recombivax, Merck Sharpe \& Dohme, and later $10 \mu \mathrm{g}$ Energix B, SmithKline Beecham), and group 6 received plasma derived vaccine $(2.5 \mu \mathrm{g}$ Hepaccine, Cheil Foods and Chemicals). ${ }^{8}$ There were no side effects apart from transient tenderness and slight swelling at the site of injection.
Medical Research
Council
Laboratories,
PO Box 273,
Banjul, Gambia
Hilton Whittle
deputy director
Maimuna Mendy
senior scientific officer
Uga Dumpis
visiting research
fellow, Riga University
Andrew Collinson
clinical scientist
London School of
Hygiene and
Tropical Medicine,
London
WC1E 7HT
Shabbar Jaffar
senior lecturer
Michael
Wansbrough
MSc student
Andrew Hall
professor
Correspondence to:
H Whittle
hwhittle@mrc.gm
bmj.com 2002;325:569 
Table 1 Vaccine efficacy in 1998 against chronic carriage of hepatitis B virus and breakthrough infection overall by village and by age group

\begin{tabular}{|c|c|c|c|c|}
\hline & Chroni & rriage & Breakthrou & infection \\
\hline & $\begin{array}{c}\text { No infected in vaccine } \\
v \text { control }\end{array}$ & $\begin{array}{c}\text { Vaccine efficacy (\%) } \\
(95 \% \mathrm{CI})\end{array}$ & $\begin{array}{c}\text { No infected in vaccine } \\
v \text { control }\end{array}$ & $\begin{array}{c}\text { Vaccine efficacy (\%) } \\
(95 \% \mathrm{CI})\end{array}$ \\
\hline Overall & $10 / 855$ v 191/931 & 94 (89 to 97 ) & $102 / 847$ v 564/929 & 80 (76 to 84$)$ \\
\hline Keneba & $6 / 628 v 83 / 622$ & 93 (84 to 97$)$ & $68 / 624$ v302/620 & 78 (72 to 82$)$ \\
\hline Manduar & $4 / 227$ v 108/309 & 95 (87 to 98$)$ & $34 / 223$ v 246/309 & 81 (74 to 86$)$ \\
\hline$<5$ years (group 6) & $3 / 235$ v 68/354 & 93 (79 to 98$)$ & $14 / 232$ v 140/354 & 85 (74 to 91$)$ \\
\hline 5-9 years (group 5) & $0 / 225$ v 66/309 & 100 & $10 / 224$ v 309/509 & 93 (85 to 96$)$ \\
\hline 10-14 years (group 4) & $2 / 220$ v 39/191 & 96 (82 to 99 ) & $33 / 220$ v 156/190 & 82 (75 to 87$)$ \\
\hline$\geqslant 15$ years (groups $1,2,3$ ) & $5 / 175$ v 18/77 & 88 (68 to 95$)$ & $53 / 171 \vee 68 / 76$ & 65 (56 to 73$)$ \\
\hline
\end{tabular}

Concentrations of antibody to hepatitis B virus surface antigen (anti-HBsAg) were measured two months after vaccination (peak antibody), and this and other tests for hepatitis B virus core antibody (anti-HBc) and hepatitis B virus surface antigen ( $\mathrm{HBsAg}$ ) were carried out at each survey. The laboratory and statistical methods, the definitions of infection, breakthrough infection, chronic carriage, and the full details of the vaccine regimens have been described previously. ${ }^{8}$ The study and consent procedures were approved by the Gambian government and the Medical Research Council ethics committee.

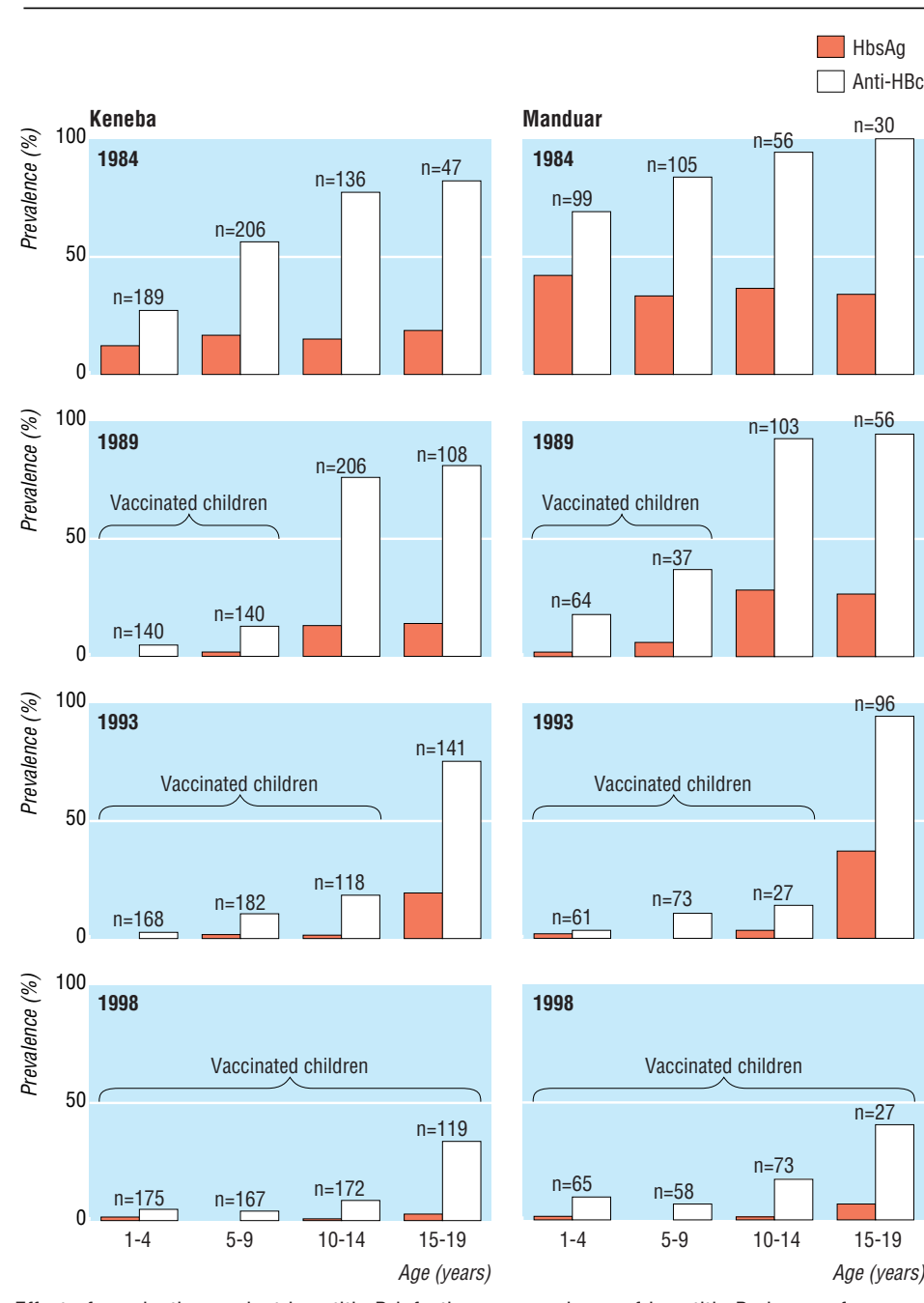

Effect of vaccination against hepatitis $B$ infection on prevalence of hepatitis $B$ virus surface antigen $(\mathrm{HBsAg})$ and hepatitis $B$ virus core antibody (anti-HBc) in two villages in the Gambia

\section{Results}

By the time of the 1998 survey 1041 young people (833 aged 0 - 14 years, 208 aged $\geqslant 15$ years) had been vaccinated in the two villages. We excluded from the study 29 infants who were below 1 year of age and 23 children who had received two or fewer doses of vaccine, leaving 989 children. Of these 989,856 gave a blood sample, 64 refused to take part, 33 had died, and 36 could not be traced; coverage ranged from $94 \%$ for children aged 1-4 years to $81 \%$ for those between 15 and 19 years.

\section{Effect of vaccination on pattern of infection}

The figure shows that in 1984 at the start of vaccination Manduar had a much higher prevalence of hepatitis B virus infection and HBsAg carriage compared with Keneba. Between 1984 and 1998 vaccination dramatically reduced the prevalence of hepatitis B virus infection in children from $48 \%(302 / 620)$ to $11 \%(68 / 624)$ in Keneba and from 80\% (246/309) to 15\% (34/223) in Manduar. The corresponding changes in HBsAg carriage rates were from $13 \%(83 / 622)$ to $1 \%(6 / 628)$ in Keneba and from $35 \%(108 / 309)$ to $2 \%(4 / 227)$ in Manduar.

\section{Vaccine efficacy by village and age}

Overall, crude vaccine efficacy against HBsAg carriage was $94 \%$ (95\% confidence interval $89 \%$ to $97 \%$ ), which did not vary significantly between villages or by age group (table 1). Overall crude vaccine efficacy against infection was $80 \%(76 \%$ to $84 \%)$, which did not vary between villages but differed according to age group, being significantly lower among those aged $\geqslant 15$ years compared with any of the other younger age categories $(\mathrm{P}<0.001)$. After we adjusted for age and village, the overall vaccine efficacy against carriage was $94 \%(89 \%$ to $97 \%$ ) and against infection was $82 \%$ (78\% to $85 \%)$.

\section{Duration of response and breakthrough infections in children immunised in $\mathbf{1 9 8 4}$}

Table 2 shows the data obtained from groups 1, 2, and 3 at the various surveys. These participants had a median age in 1998 of 16.2 years (range 14.2-21.7 years) and had been followed up for a median of 13.8 (13.5-14.1) years. In each of the groups, which had significantly different peak antibody responses in 1985 $(\mathrm{P}<0.0001)$, antibody decayed in a similar and regular exponential manner with time. The proportion of uninfected participants with undetectable antibody concentrations $(<10 \mathrm{mIU} / \mathrm{ml})$ differed between the groups $(\mathrm{P}=0.001)$ and increased with time $(\mathrm{P}<0.0001)$.

The proportion of breakthrough infections and the cumulative proportion of breakthrough infections 
(consisting of current infections and past infections that were no longer detectable) also increased with time ( $\mathrm{P}<0.0001$ in both cases), but neither of these proportions differed significantly between the groups. By 1998, 64 of the 171 (37.4\%) vaccinated participants had been infected, and of the 111 uninfected participants, $40(36 \%)$ had undetectable concentrations of antibody.

Vaccine efficacy against infection was $49.2 \%(27.8 \%$ to $64.3 \%$ ), $36.2 \%$ (4.7\% to $57.3 \%$ ), and $92.3 \%$ (57.2\% to $100 \%$ ) for groups 1,2 , and 3 , respectively $(\mathrm{P}<0.01$ for comparison between group 1 or 2 and 3). In 1998 one of $54(2 \%), 4$ of $57(7 \%)$, and none of 64 participants in groups 1,2, and 3 were chronic carriers of HBsAg. Two of the chronic carriers were infected within a year of vaccination; the three others were infected five or more years later. Vaccine efficacy against chronic carriage was $91.0 \%$ (36.8\% to $98.7 \%), 65.8 \%$ ( $11.3 \%$ to $86.8 \%)$, and $100 \%$ for groups 1,2 , and 3, respectively.

Breakthrough infections and chronic carriage according to peak antibody responses

Table 3 shows that the number of breakthrough infections was related to vaccination group $(\mathrm{P}=0.01)$ and to the peak antibody concentration $(\mathrm{P}=0.001)$. Those with an undetectable (equivalent to $<10 \mathrm{mIU} / \mathrm{ml}$ ) response had six times the chance of infection compared with those with high responses $(>999 \mathrm{mIU} / \mathrm{ml})$. More importantly, participants whose peak antibody response was $<10 \mathrm{mIU} / \mathrm{ml}$ were 75 times more likely to become chronic carriers than those with responses $\geqslant 10 \mathrm{mIU} / \mathrm{ml}(\mathrm{P}<0.0001)$. Seven out of the 10 chronic carriers, all of whom had a peak antibody response of less than $10 \mathrm{mIU} / \mathrm{ml}$, were infected before the age of 5 years.

\section{Logistic regression analyses of breakthrough} infections and chronic carriage

Table 4 shows the independent factors associated with breakthrough infection. Time since vaccination and peak antibody concentrations were strongly associated; sex and village had a significant but lesser effect. Dose (three or four) was not significant; neither was route of administration.

The only factor associated with chronic carriage of hepatitis B virus was a peak response of $<10 \mathrm{mIU} / \mathrm{ml}$ (8/39 (20.5\%) versus $2 / 731(0.27 \%)$ children with a higher response (odds ratio 95, 95\% confidence interval 19 to 466$)$ ).

\section{Discussion}

We have shown that despite low antibody concentrations, vaccine efficacy against chronic carriage of hepa-
Table 2 Concentrations of antibody to hepatitis B surface antigen (anti-HbsAg) and number infected over time among vaccinated children in groups 1-3

\begin{tabular}{|c|c|c|c|c|c|}
\hline Year of survey & $\begin{array}{c}\text { No } \\
\text { tested }\end{array}$ & $\begin{array}{c}\text { Proportion (\%) with } \\
\text { anti-HBsAg }<10 \mathrm{mlU} / \mathrm{ml} \\
\text { among those uninfected }\end{array}$ & $\begin{array}{c}\text { Geometric mean } \\
(95 \% \mathrm{Cl}) \text { anti- } \mathrm{HBsAg} \\
(\mathrm{mIU} / \mathrm{ml}) \neq \text { among those } \\
\text { uninfected }\end{array}$ & $\begin{array}{l}\text { No } \\
\text { infected } \\
\text { at time } \\
\text { of survey }\end{array}$ & $\begin{array}{c}\text { No ever } \\
\text { infected§}\end{array}$ \\
\hline \multicolumn{6}{|l|}{ Group 1} \\
\hline 1985 & 53 & $8 / 47(17)$ & 302 (216 to 422$)$ & 7 & 7 \\
\hline 1989 & 48 & 9/37 (24) & 60 (37 to 97 ) & 10 & 11 \\
\hline 1993 & 47 & $4 / 30(13)$ & 31 (21 to 46$)$ & 15 & 19 \\
\hline 1998 & 52 & $11 / 30(37)$ & 67 (38 to 120) & 21 & 24 \\
\hline \multicolumn{6}{|l|}{ Group 2} \\
\hline 1985 & 57 & $3 / 50(6)$ & 579 (421 to 796$)$ & 7 & 7 \\
\hline 1989 & 53 & $10 / 42(24)$ & 65 (45 to 95$)$ & 11 & 11 \\
\hline 1993 & 49 & $5 / 37(14)$ & 32 (24 to 44$)$ & 10 & 16 \\
\hline 1998 & 56 & $12 / 34(35)$ & 60 (30 to 120) & 18 & 23 \\
\hline \multicolumn{6}{|l|}{ Group 3} \\
\hline 1985 & 62 & $0 / 62(0)$ & 1045 (758 to 1442) & 2 & 2 \\
\hline 1989 & 61 & 3/55 (5) & 134 (83 to 216) & 4 & 6 \\
\hline 1993 & 59 & $5 / 47(11)$ & 97 (59 to 162) & 8 & 12 \\
\hline 1998 & 63 & $17 / 47(36)$ & 79 (45 to 140$)$ & 14 & 17 \\
\hline
\end{tabular}

* Refers to total number tested for anti-HB core antigen but not necessarily for anti-HBsAg †Uninfected at time of survey.

$\ddagger$ Excludes those with anti-HBs $<10 \mathrm{mlU} / \mathrm{ml}$.

§Includes current and past infections.

titis B virus is remarkably well maintained in adolescence. However, vaccine efficacy against infection was also well maintained as $37 \%$ of teenagers were infected and $36 \%$ of those who were uninfected had undetectable concentrations of anti-HBs.

\section{Natural boosting and immunity}

The role of natural boosting in maintaining immunity in highly endemic settings is not clear. In our study antibody concentrations in uninfected older teenagers stabilised over the previous four years, perhaps as a result of increased exposure by the sexual route. In a larger cohort of Gambian people vaccinated in infancy, we have noted transient rises in antibody concentrations, which may be due to transient infections and which probably boost both cellular and humoral immunity. ${ }^{10}{ }^{11}$ The role, if any, that sexual exposure plays in maintaining and boosting immunity remains to be defined and at present there are insufficient data to decide if a booster dose would be useful in teenagers in highly endemic areas where $15 \%$ of sexual partners may be chronic carriers of hepatitis B virus. ${ }^{42}$ In an area of low endemicity teenagers vaccinated in infancy may lose immunity because of lack of exposure, and a booster dose may be necessary at the onset of sexual maturity. In this setting it may be more sensible to deliver the primary course of vaccine in adolescence.

Table 3 Hepatitis B virus infection and chronic carriage in 1998 in relation to peak antibody concentration. Figures are numbers of breakthrough infections out of total number of children with antibody response

\begin{tabular}{lccccc} 
& \multicolumn{5}{c}{ Peak antibody concentration (mIU/mI) } \\
\cline { 2 - 6 } Group and time of vaccination & $<\mathbf{1 0}$ & $\mathbf{1 0 - 9 9}$ & $\mathbf{1 0 0 - 9 9 9}$ & $>\mathbf{9 9 9}$ & Total \\
\hline Group 1 (Nov 84-May 85) & $9^{*} / 10(90)$ & $5 / 9(56)$ & $4 / 26(15)$ & $3 / 6(50)$ & $21 / 51(41)$ \\
\hline Group 2 (Nov 84-May 85) & $3+/ 5(60)$ & $1 / 3(33)$ & $11 / 32(34)$ & $3 * / 16(19)$ & $18 / 56(32)$ \\
\hline Group 3 (Nov 84-May 85) & $0 / 0$ & $2 / 2(100)$ & $4 / 22(18)$ & $8 / 39(21)$ & $14 / 63(22)$ \\
\hline Group 4 (Oct 85-Sep 89) & $2 * / 5(40)$ & $1 / 8(13)$ & $10^{*} / 37(27)$ & $11 / 141(8)$ & $24 / 191(13)$ \\
\hline Group 5 (Oct 89-Sep 93) & $0 / 1$ & $0 / 9$ & $4 / 34(12)$ & $5 / 146(3)$ & $9 / 190(5)$ \\
\hline Group 6 (Oct 93-Jul 98) & $5+/ 18(28)$ & $3 / 27(11)$ & $3 / 73(4)$ & $3 / 101(3)$ & $14 / 219(6)$ \\
\hline Overall & $19 / 39(49)$ & $12 / 58(21)$ & $36 / 224(16)$ & $33 / 449(7)$ & $100 / 770(13)$ \\
\hline
\end{tabular}

${ }^{\star}$ One breakthrough infection resulted in chronic carriage.

†Three breakthrough infections resulted in chronic carriage. 


\begin{tabular}{|c|c|c|c|}
\hline Variable & $\begin{array}{l}\text { No (\%) of breakthrough } \\
\text { infections }\end{array}$ & $\begin{array}{l}\text { Adjusted odds ratio } \\
(95 \% \mathrm{Cl})\end{array}$ & $\begin{array}{c}P \text { value for } \\
\text { variable }\end{array}$ \\
\hline \multicolumn{4}{|c|}{ Vaccination group (median time (years) since vaccination): } \\
\hline Group 1 (13.6) & $21 / 52(40)$ & 8.9 (3.8 to 20.8 ) & \multirow{6}{*}{0.0001} \\
\hline Group 2 (13.6) & $18 / 56(32)$ & 9.0 (3.8 to 21.1) & \\
\hline Group 3 (13.6) & $14 / 63(22)$ & 7.7 (3.2 to 18.5$)$ & \\
\hline Group 4 (10.7) & $25 / 220(11)$ & $3.3(1.6$ to 7.1$)$ & \\
\hline Group $5(6.3)$ & $9 / 202(4)$ & $1.3(0.5$ to 3.3$)$ & \\
\hline Group $6(2.1)$ & $15 / 254(6)$ & 1.0 & \\
\hline \multicolumn{4}{|l|}{ Sex: } \\
\hline Male & $60 / 426(14)$ & 1.6 (1.0 to 2.6$)$ & \multirow{2}{*}{0.04} \\
\hline Female & $42 / 421(10)$ & 1.0 & \\
\hline \multicolumn{4}{|c|}{ Peak antibody (mlU/ml): } \\
\hline$<10$ & $19 / 39(49)$ & 11.9 (4.9 to 28.8$)$ & \multirow{4}{*}{0.0001} \\
\hline $10-99$ & $12 / 58(21)$ & 3.4 (1.5 to 7.8$)$ & \\
\hline $100-999$ & $36 / 224(16)$ & 1.8 (1.0 to 3.2$)$ & \\
\hline$\geqslant 1000$ & $33 / 449(7)$ & 1.0 & \\
\hline \multicolumn{4}{|l|}{ Village: } \\
\hline Manduar & $34 / 223(15)$ & $1.8(1.1$ to 3.0$)$ & \multirow{2}{*}{0.03} \\
\hline Keneba & 68/624 (11) & 1.0 & \\
\hline
\end{tabular}

\section{Risk factors for breakthrough infection}

Independent risk factors associated with breakthrough infection were sex, village, time since vaccination, and peak antibody response. Boys and young men had a higher risk, as did people living in Manduar, which before vaccination had a remarkably high rate of infection of $71 \%$ in young children over a four year period. ${ }^{5}$ As age and type of vaccine were directly linked in groups 4,5 , and 6 we were not able to analyse these effects separately for the whole dataset. However, in participants in groups 1,2 , and 3 , who were simultaneously given different doses by different routes, time since vaccination seemed to be a major determinant. Breakthrough infections and chronic carriage were clearly and strongly related to peak antibody concentrations. Thus half of the children who failed to produce detectable concentrations of antibody became infected, most within the first five years after vaccination, and of those infected nearly half became chronic carriers. However, as the numbers were small and as vaccines, dose, and routes of administration varied we were not able to assess formally which of these factors were the most important determinants of breakthrough infections resulting in chronic carriage of hepatitis B virus.

\section{What is already known on this topic}

An expert panel has declared that booster immunisations are not needed for lifelong immunity to hepatitis B

The evidence for maintenance of immunity in teenagers after vaccination in infancy is slender

The risk of hepatitis B virus infection is increased by sexual exposure

\section{What this study adds}

Teenagers vaccinated in infancy have low concentrations of antibody to hepatitis B surface antigen

Even though breakthrough infections are common at this age, protection against chronic infections with hepatitis B virus may be maintained

\section{Other long term follow up studies}

Few of the follow up studies of infants or young children vaccinated against hepatitis $\mathrm{B}$ virus have lasted longer than 10 years. ${ }^{9}{ }^{13-15}$ The longest was in China, where 52 of the original 477 children (11\%) were followed for 15 years: half had detectable concentrations of anti-HBs, and vaccine efficacy was $86.6 \%$ for chronic carriage and $86.4 \%$ for infection. ${ }^{15}$ This small study with a large dropout rate formed the basis for a recent consensus statement that no hepatitis B virus booster was required for 15 years after primary vaccination. ${ }^{16}$ However as the age at first sexual intercourse may be higher in China than in Africa the findings may not be generally applicable to other groups who start sexual activity earlier. ${ }^{17}$

In conclusion, our long term study of hepatitis B vaccination in infancy in a country where the infection is endemic showed that vaccine efficacy against infection waned with time but efficacy against chronic infection remained high over 14 years. However, the numbers involved are relatively small and a larger study of efficacy during adolescence is necessary before we conclude that a booster dose is not needed before the onset of sexual activity. ${ }^{16}$ In Africa and elsewhere, the risk of infection and of chronic carriage might be increased by the presence of other sexually transmitted infections, as is the case for HIV- $1 .^{18}$

We thank Lamin Giana, Joseph Bass, and Adam Jeng for their help in the laboratory and field.

Contributors: HW, SJ, and AH planned the study, contributed to the fieldwork and analysis, and wrote the paper. SJ organised and analysed the data. MW, UD, and AC played a major role in the fieldwork and contributed to writing the paper. MM was responsible for the laboratory work and helped in the field.

Funding: Medical Research Council (UK) and Merck Sharpe \& Dohme (USA)

Competing interests: None declared.

1 World Health Organization. Prevention of primary liver cell cancer. Report on a meeting of a WHO scientific group. Lancet 1983;i:463-65.

2 Kane MA, Clements J, Hu D. Hepatitis B. In: Jamison OT, Mosley WH, Measham AR, Bobadilla J, eds. Disease control priorities in developing countries. A World Bank Book. New York: Oxford University Press, 1993:321-30.

3 Gambia Hepatitis Study Group. The Gambia hepatitis intervention study. Cancer Res 1987;47:5782-7.

4 Whittle HC, Bradley AK, McLauchlen K, Ajdukiewicz AB, Howard CR, Zuckerman AJ, et al. Hepatitis B infection in two Gambian villages. Lancet 1983;i:1203-6.

5 Whittle H, Inskip H, Bradley AK, McLaughlan K, Shenton F, Lamb W, et al. The pattern of childhood hepatitis B infection in two Gambian villages.J Infect Dis 1990;161:1112-5.

6 Whittle HC, Lamb WH, Ryder RW. Trials of intradermal hepatitis B vaccines in Gambian children. Ann Trop Paediatr 1987;7:6-9.

7 Whittle HC, Inskip H, Hall AJ, Mendy M, Downes R, Hoare S. Vaccination against hepatitis $\mathrm{B}$ and protection against chronic viral carriage in the Gambia. Lancet 1991:337:747-50.

8 Whittle HC, Maine N, Pilkington J, Mendy M, Fortuin M, Bunn J, et al. Long-term efficacy of continuing hepatitis $\mathrm{B}$ vaccination in infancy in two Gambian villages. Lancet 1995;345:1089-92.

9 Coursaget P, Leboulleux P, Soumare M, le Cann P, Yvonnst B, Chiron JP, et al. Twelve year follow up study of hepatitis B immunization of Senegalese infants.J Hepatol 1994;21:250-4.

10 Gambia Hepatitis Intervention Study. Annual report, 1996. Lyons: International Agency for Research on Cancer, 1996:12.

11 Jack AD, Hall AJ, Maine M, Mendy M, Whittle HC. What level of hepatitis B antibody is protective? J Infect Dis 1999;179:489-92.

12 Vall-Mayans M, Hall AJ, Inskip HM, Chotard J, Lindsay SW, Coromina E, et al. Risk factors for transmission of hepatitis B virus to Gambian children. Lancet 1990;336:1107-9.

13 Chen HL, Chang MH, Ni YH, Hsu HY, Lee PI, Lee CY, et al. Sero-epidemiology of hepatitis B virus infection in children: ten years of mass vaccination in Taiwan. JAMA 1996;276:906-8

14 Yuen MF, Lim WL, Cheng LC, Lam SK, Lai CL. Twelve-year follow-up of a prospective randomized trial of hepatitis B recombinant DNA yeast vaccine versus plasma-derived vaccine without booster doses in children. Hepatology 1999;29:924-7.

15 Liao SS, Li RC, Li H, Yang JY, Aeng XJ, Gong J, et al. Long-term efficacy of plasma derived vaccine: a 15-year follow-up study among Chinese children. Vaccine 1999;17:2661-6. 
16 European Consensus Group on Hepatitis B Immunity. Are booster immunisations needed for lifelong hepatitis B immunity? Lancet 2000;355:561-5.

17 Ratcliffe A, Hill A, Walraven G. Separate lives, different interests: male and female reproduction in the Gambia. Bull World Health Organ 2000;78:570-9.
18 Grosskurth H, Moshu F, Todd J, Mwijarubi E, Klokke A, Senkoro K, et al. Impact of improved treatment of sexually transmitted diseases on HIV infection in rural Tanzania: randomised controlled trial. Lance 1995;346:530-6.

(Accepted 23 April 2002) 